\title{
Determinan dan Trend Kemiskinan di Kabupaten Wonosobo Provinsi Jawa Tengah
}

\author{
Farida Nur Isnaini $^{1^{*}}$, Abdul Aziz Ahmad ${ }^{2}$, Suharno ${ }^{3}$ \\ ${ }^{1}$ Mahasiswa Magister Ekonomi, Fakultas Ekonomi dan Bisnis, Universitas Jenderal Soedirman \\ ${ }^{2,3}$ Dosen Ilmu Ekonomi dan Studi Pembangunan, Fakultas Ekonomi dan Bisnis, Universtas Jenderal Soedirman \\ *Correspondence email: farida.isnaini@gmail.com, ${ }^{2}$ email: rekan.aziz@gmail.com, ${ }^{3} \mathrm{email}$ : suharno@unsoed.ac.id
}

\begin{abstract}
This study aims to analyze the effect of population, education, regional Minimum Wages, inflation, and Gross Regional Domestic Product on poverty and analyze poverty trends in Wonosobo Regency. This study uses secondary data in the form of time series data with an observation period of 2002-2017 and the research method is multiple linear regression with the Ordinary Least Square model. The analysis shows that education, regional minimum wages and gross regional domestic product have a negative and significant impact on poverty in Wonosobo Regency. Population growth, and inflation does not have a significant effect on poverty in Wonosobo Regency. In addition, the future poverty trend of Wonosobo Regency is negative. These findings imply the first need for skills and expertise training programs in improving the quality of education. Second, the government must increase regional minimum wages, so that people can meet their daily needs. The government needs to increase economic growth in all sectors of the economy by using its potential.
\end{abstract}

Keywords: Poverty, Population growth, Education, Regional Minimum Wages, Inflation, and Gross Regional Domestic Product

\section{PENDAHULUAN}

Pembangunan merupakan usaha untuk menciptakan kesejahteraan rakyat, sehingga hasil pembangunan harus dapat dinikmati oleh seluruh rakyat secara adil dan merata. Berbagai kebijakan pembangunan dilakukan untuk mencapai pertumbuhan ekonomi yang tinggi dengan memanfaatkan potensi dan sumber daya yang ada. Namun pertumbuhan ekonomi tersebut harus diikuti dengan penurunan tingkat kemiskinan dan pemerataan distribusi pendapatan (Todaro dan Smith, 2006). Dampak kemiskinan sangat kompleks, penduduk miskin akan kesulitan memenuhi kebutuhan pangannya, sehingga akan berpengaruh pada tingkat kesehatan dan tingkat produktivitas. Produktivitas rendah akan menyebabkan penghasilan yang rendah pula, sehingga penduduk miskin akan semakin kesulitan dalam memenuhi kebutuhan hidupnya (Sekhampu, 2013). Kemiskinan juga mendorong meningkatnya urbanisasi karena orang berpikir untuk mencari pekerjaan di kota dengan harapan memperoleh penghasilan yang lebih tinggi (Suryawati, 2005).. Hal ini justru mengakibatkan masalah dalam penyediaan berbagai sarana dan kebutuhan penduduk misalnya terjadi ketidakseimbangan antara angkatan kerja dengan lapangan kerja yang pada akhirnya menimbulkan pengangguran diperkotaan (Kuncoro, 2009)

Mengingat dampak kemiskinan yang begitu banyak, maka pengentasan kemiskinan telah menjadi tujuan pembangunan yang fundamental untuk menilai efektivitas berbagai jenis program pembangunan. Berbagai penanggulangan kebijakan seperti Intruksi Presiden Desa Tertinggal (IPDT), Program Jaring Pengaman Sosial (JPS), dan Operasi Pasar Khusus (OPK), Program Pengembangan Kecamatan (PPK), serta pemberian beras untuk keluarga miskin (RASKIN), Bantuan Langsung Tunai (BLT), Kredit Usaha Rakyat (KUR), Kartu Indonesia Pintar (KIP), Kartu Indonesia Sehat (KIS), yang diperuntukan pada sektor keluarga miskin dan Bantuan Operasional Sekolah (BOS) yang diberikan kepada siswa/siswi yang kurang mampu menempuh pendidikan serta bantuan lainnya yang dapat mengurangi jumlah kemiskinan dalam mewujudkan kesejahteraan masyarakat (Kementerian Sosial, 2015). Persoalan kemiskinan tidak hanya sekedar berapa jumlah dan presentase penduduk miskin tetapi dimensi lain yang perlu diperhatikan adalah tingkat kedalaman kemiskinan. Selain harus mampu memperkecil jumlah penduduk miskin, kebijakan kemiskinan juga sekaligus harus dapat mengurangi kedalaman kemiskinan. Kemiskinan juga merupakan salah satu persoalan mendasar yang menjadi pusat perhatian pemerintah di Provisi Jawa Tengah, khususnya di Kabupaten Wonosobo. Kabupaten Wonosobo merupakan kabupaten dengan tingkat kemiskinan yang tinggi diantara Kabupaten yang ada di Provinsi Jawa Tengah. 
Tabel 1

10 Besar Proporsi penduduk miskin Kabupaten di Jawa Tengah tahun 2016-2017

\begin{tabular}{|c|c|c|c|c|c|c|c|}
\hline \multirow[b]{2}{*}{ No } & \multirow[b]{2}{*}{ Kabupaten } & \multicolumn{2}{|c|}{2016} & \multicolumn{4}{|c|}{2017} \\
\hline & & $\begin{array}{l}\text { Penduduk } \\
\text { Miskin }\end{array}$ & $\begin{array}{c}\text { Jumlah } \\
\text { Penduduk }\end{array}$ & Proporsi (\%) & $\begin{array}{l}\text { Penduduk } \\
\text { Miskin }\end{array}$ & $\begin{array}{c}\text { Jumlah } \\
\text { Penduduk }\end{array}$ & Proporsi (\%) \\
\hline 1 & Wonosobo & 160.100 & 780.793 & 20,50 & 159.200 & 784.207 & 20,30 \\
\hline 2 & Kebumen & 235.900 & 1.188 .603 & 19,84 & 233.400 & 1.192 .007 & 19,58 \\
\hline 3 & Brebes & 348.000 & 1.788 .880 & 19,45 & 343.500 & 1.796 .004 & 19,12 \\
\hline 4 & Purbalingga & 171.800 & 907.507 & 18,93 & 171.900 & 916.427 & 18,75 \\
\hline 5 & Rembang & 115.500 & 624.096 & 18,50 & 115.200 & 628.922 & 18,31 \\
\hline 6 & Pemalang & 227.100 & 1.292 .609 & 17,56 & 225.000 & 1.296 .281 & 17,35 \\
\hline 7 & Banjarnegara & 158.200 & 907.410 & 17,43 & 156.800 & 912.917 & 17,17 \\
\hline 8 & Banyumas & 283.900 & 1.650 .625 & 17,19 & 283.200 & 1.665 .025 & 17,00 \\
\hline 9 & Klaten & 168.000 & 1.163 .218 & 14,44 & 165.000 & 1.167 .401 & 14,13 \\
\hline 10 & Sragen & 126.800 & 882.090 & 14,37 & 124.000 & 885.122 & 14,00 \\
\hline
\end{tabular}

Sumber: Badan pusat statistik (BPS) Jawa Tengah, 2018

Tabel 1 menunjukan bahwa 10 besar jumlah penduduk dan penduduk miskin Kabupaten di Provinsi Jawa Tengah berfluktuasi tetapi cenderung menurun. Jumlah penduduk miskin tertinggi di Jawa Tengah adalah di Kabupaten Wonosobo. Dengan demikian, perlunya analisis lebih lanjut menganai faktor yang memengaruhi kemiskinan di Kabupaten Wonosobo. Terdapat faktor-faktor yang menyebabkan seseorang atau sebuah keluarga miskin, salah satunya adalah rendahnya taraf pendidikan (Widodo, 2006) padahal telah diketahui bahwa kualitas sumber daya manusia seseorang bisa dilihat dari tingkat pendidikannya, pendidikan yang semakin rendah menggambarkan kualitas sumber daya manusianya rendah dan dapat menyebabkan penduduk miskin. Semakin tinggi pendidikan seseorang kesempatan untuk mendapat kehidupan lebih baik semakin besar, karena mempunyai kualitas dalam mencari pekerjaan (Suryahadi dan Sumarto, 2001).

Faktor yang mempengaruhi tingkat kemiskinan selanjutnya yaitu upah minimum. Semakin meningkat upah minimum akan meningkatkan pendapatan masyarakat sehingga kesejahteraan juga meningkat dan sehingga terbebas dari kemiskinan (Kaufman, 2000). Selain itu inflasi merupakan indikator yang berpengaruh terhadap tingkat kemiskinan. Inflasi akan menimbulkan beberapa akibat buruk kepada individu, masyarakat dan kegiatan perekonomian secara keseluruhan. Salah satu akibat penting dari inflasi adalah cenderung menurunkan taraf kemakmuran segolongan besar masyarakat. Selain jumlah penduduk, pendidikan, upah minimum, dan inflasi, faktor lain yang mempengaruhi kemiskinan adalah Produk Domestik Regional Bruto (PDRB). Produk Domestik Regional Bruto (PDRB) akan menimbulkan beberapa dampak seperti peningkatan pertumbuhan ekonomi, kesejahteraan masyarakat melalui nilai tambah barang dan jasa yang diterima oleh daerah sehingga dapat mengurangi tingkat kemiskinan, dan mengantisipasi masalah sosial lainnya. Menurut Todaro dan Smith (2006) selain menciptakan pertumbuhan ekonomi proses pembangunan haruslah berimbas terhadap pengurangan angka kemiskinan, ketimpangan pendapatan, serta peningkatan penyerapan tenaga kerja. Kemiskinan di Indonesia adalah salah satu masalah yang sulit diatasi sejak dulu khususnya di Kabupaten Wonosobo. Kabupaten Wonosobo merupakan Kabupaten dengan tingkat kemiskinan tertinggi di Provinsi Jawa Tengah. Oleh sebab itu agar masalah kemiskinan bisa dituntaskan secara optimal perlu pengkajian terlebih dahulu untuk mengetahui faktor-faktor apa saja yang mempengaruhi tingkat kemiskinan di Kabupaten Wonosobo. Dengan demikian tujuan dari peneilitian ini pertamama menganalisis pengaruh juma penduduk, pendidikan, upah minimum kabupaten, infalsi, dan produk domestik regional terhadap kemiskinan di Kabupaten Wonosobo, kedua menganalisis trend tingkat kemiskinan di Kabupaten Wonosobo.

\section{METODE}

Penelitian ini digunakan pendekatan kuantitatif. Pendekatan kuantitatif pada dasarnya menekankan analisisnya pada data-data numerikal (angka) yang diolah dengan metode statistika. Pada metode kuantitatif, akan diperoleh signifikansi perbedaan kelompok atau signifikansi hubungan antar variabel yang diteliti (Wirartha, 2006). Data yang digunakan dalam penelitian ini adalah data sekunder berupa data tingkat kemiskinan, jumlah penduduk diukur dengan satuan jiwa, pendidikan, upah minimum, inflasi, dan Produk Domestik Regional Bruto (PDRB) dengan menggunakan data berkala (time series) periode 2002-2017. Data yang digunakan dalam penelitian ini diolah menggunakan software Eviews dengan bantuan Microsoft Excel.

Tahap pertama yang harus dilakukan adalah ouput regresi harus lolos uji asumsi klasik. Terdapat beberapa asumsi dasar yang dapat menghasilkan estimator linear tidak bias atau Best Linier Unbiased Estimator (BLUE) yang terbaik dari model regresi yang diperoleh dari model Ordinary Least Square (OLS). Dengan terpenuhinya asumsi tersebut, maka hasil yang diperoleh dapat lebih akurat dan mendekati atau sama dengan kenyataan, dimana asumsi asumsi dasar itu dikenal sebagai asumsi klasik. Untuk mendapatkan hasil memenuhi sifat tersebut dilakukan pengujian asumsi klasik yang meliputi, uji multikolinearitas, uji heteroskedatisitas, dan uji autokorelasi (Gujarati, 2012). Untuk 
mengetahui sejauh mana pengaruh variabel jumlah penduduk, pendidikan, upah minimum, inflasi dan Produk Domestik Regional Bruto (PDRB). Dianalisis menggunakan analisis regresi berganda yang dinyatakan dalam bentuk fungsi sebagai berikut.

$K=\beta_{0}+\beta_{1} J P_{1}+\beta_{2} P D D K_{2}+\beta_{3} U M K_{3}+\beta_{4} I N F_{4}+\beta_{5} P D R B_{5}+e$

Keterangan: K: Tingkat kemiskinan dinyatakan dalam persen; $\beta_{0}$ : Konstanta; $\beta_{1-5}$ : Koefisien regresi; JP: Jumlah penduduk diukur dengan satuan jiwa; PDDK: Pendidikan yang dinyatakan dalam satuan persen; UMK: Upah minimum kabupaten yang dinyatakan dalam satuan rupiah; INF: Inflasi yang dinyatakan dalam satuan persen; PDRB

: PDRB yang dinyatakan dalam satuan persen.

Untuk mengetahui perkembangan trend kemiskinan di Kabupaten Wonosobo menggunakan analisis trend dengan garis tidak lurus (trend parabola dan trend eksponential (logaritma). Dalam penelitian ini hubungan linear variabel kemiskinan dengan variabel nilai periode tahun dapat ditulis dalam persamaan regresi sebagai berikut.

$\log ^{\wedge} Y=\log a+X \log b$

Keterangan : $\log ^{\wedge} \mathrm{Y}:$ Nilai trend; $\mathrm{X}$ : Nilai periode tahun; $\log a$ : Nilai konstanta yaitu nilai y pada saat nilai $\mathrm{x}=0$; $\log b$ : Nilai kemiringan yaitu tambahan y, apabila $\mathrm{x}$ bertambah satu satuan.

\section{HASIL}

Sebelum dilakukan pembahasan lebih lanjut mengenai hasil estimasi regresi mengenai pengaruh jumlah penduduk, pendidikan, upah minimum kabupaten, inflasi, dan PDRB terhadap kemiskinan di Kabupaten Wonosobo, terlebih dahulu dilakukan uji asumsi klasik yang meliputi uji multikolinearitas, uji heteroskedastisitas, dan uji autokorelasi. Pengujian multikolinieritas dilakukan untuk menguji apakah dalam sebuah model terdapat hubungan linier antara variabel bebas (X) dalam suatu model regresi. Suatu model regresi dikatakan terkena multikolinieritas bila terjadi hubungan linier yang sempurna atau pasti diantara beberapa atau seluruh variabel bebas (X) dari suatu model regresi. Akibat yang ditimbulkan ialah terdapat kesulitan untuk melihat pengaruh variabel bebas (X) terhadap variabel terikat $(\mathrm{Y})$.

Tabel 2.

Hasil Uji Multikolinieritas

\begin{tabular}{lrl}
\hline \multicolumn{1}{c}{ Variabel } & VIF & \multicolumn{1}{c}{ Kesimpulan } \\
\hline Jumlah Penduduk & 1,402386 & Tidak Terjadi Multikolinearitas \\
Pendidikan & 2,447320 & Tidak Terjadi Multikolinearitas \\
Upah Minimum & 2,626722 & Tidak Terjadi Multikolinearitas \\
Inflasi & 1,168083 & Tidak Terjadi Multikolinearitas \\
PDRB & 3,553755 & Tidak Terjadi Multikolinearitas \\
\hline
\end{tabular}

Sumber: Data olahan

Uji multikolinieritas dengan metode variance inflation factors (VIF) masing-masing variabel. Nilai centered VIF variabel tidak boleh lebih dari 10. Hasil uji dengan VIF menunjukan bahwa nilai Centered VIF masing-masing variabel lebih kecil dari 10 atau VIF < 10. Dengan demikian, dapat disimpulkan bahwa pada model penelitian ini tidak terdapat permasalahan multikolinieritas. Tahapan selanjutanya adalah uji heteroskedastisitas. Uji heterokedastisitas adalah keadaan dimana faktor gangguan tidak memiliki varian yang sama. Untuk menguji heteroskedastisitas dapat dilakukan dengan metode Glejser, Untuk mengetahui ada tidaknya heteroskedastisitas dapat dilihat pada Tabel 3 berikut ini:

Tabel 3

Hasil Uji Heterokedastisitas

\begin{tabular}{|c|c|c|}
\hline Obs*R-squared & Prob. Chi-Square(5) & Kesimpulan \\
\hline 8,503354 & 0,1306 & Tidak Terjadi Heteroskedastisitas \\
\hline
\end{tabular}

Sumber: Data olahan

Tabel 3 menujukkan bahwa, nilai dimana nilai p value yang ditunjukkan dengan nilai Prob.Chi-Square(5) pada Obs*R-squared yaitu sebesar 0,8510. Dari hasil pengujian tersebut, diketahui bahwa nilai p value $>$ alpa $5 \%(\alpha=$ 0,05 ), yaitu 0,1306 > 0,05 maka model regresi bersifat homoskedastisitas atau dengan kata lain tidak ada masalah asumsi heteroskedastisitas. Pengujian yang terakhir yaitu uji autokorelasi. Pengujian autokorelasi dilakukan untuk menguji apakah dalam sebuah penelitian terdapat hubungan antara residual antar waktu pada model penelitian yang digunakan, sehingga estimasi menjadi bias. Untuk mengetahui apakah terjadi permasalahan autokorelasi, dapat dilakukan dengan menggunakan metode Breusch-Godfrey Serial Correlation LM Test. Hasil pengujian autokorelasi dapat dilihat pada Tabel 4 berikut ini: 
Tabel 4.

Hasil Uji Autokorelasi dengan Breusch-Godfrey Serial Correlation LM Test

\begin{tabular}{|l|r|l|l|}
\hline F-statistic & 0,043904 & Prob. F(2,8) & 0,9573 \\
\hline Obs*R-squared & 0,185830 & Prob. Chi-Square(2) & 0,9113 \\
\hline
\end{tabular}

Sumber: Data olahan

Dengan metode Breusch-Godfrey Serial Correlation LM Test dapat diketahui bahwa nilai Prob. Chi-Square(2) yang diperoleh adalah 0,9113 dan lebih besar dari 0,05. Dengan demikian, dapat disimpulkan bahwa tidak terjadi autokorelasi dalam model penelitian ini. Berikut ini Tabel 5 yang menunjukkan hasil estimasi regresi

Tabel 5.

Output Regresi Linier Berganda

\begin{tabular}{|c|c|c|c|}
\hline Variabel & Koefisien & t-Statistic & Prob. \\
\hline $\mathrm{C}$ & 57,026 & 5,8991 & 0,0002 \\
\hline JP & 0,0001 & 1,6051 & 0,1429 \\
\hline PDDK & $-0,7555$ & $-2,5584$ & $0,0308^{* *}$ \\
\hline UMK & $-0,0001$ & $-2,8743$ & $0,0183^{*}$ \\
\hline INF & $-0,0639$ & $-0,4924$ & 0,6342 \\
\hline PDRB & $-5,2086$ & $-2,5153$ & $0,0330^{\text {** }}$ \\
\hline $\operatorname{Adj} R^{2}$ & & & 0,80869 \\
\hline
\end{tabular}

Sumber: Data olahan

*signifikan pada level signifikansi 1\%,**signifikan pada level signifikansi $5 \%$.

Output regresi menunjukkan variabel jumlah penduduk memiliki koefisien regresi 0,0001 dan nilai prababilitas sebesar 0,1429. Hal ini menunjukkan bahwa variabel jumlah penduduk berpengaruh positif dan tidak signifikan terhadap tingkat kemiskinan Kabupaten Wonosobo. Hasil tersebut sesuai dengan teori dan penelitian terdahulu yang menjadi landasan teori dalam penelitian ini,yang mana menurut Nelson dan Leibstein (Sukirno, 2012) terdapat pengaruh langsung antara pertambahan penduduk terhadap tingkat kesejahteraan masyarakat. Nelson dan Leibstein menunjukan bahwa pertumbuhan penduduk yang pesat di negara berkembang menyebabkan tingkat kesejahteraan masyarakat tidak mengalami perbaikan yang berarti dan dalam jangka panjang akan mengalami penurunan kesejahteraan serta meningkatkan jumlah penduduk miskin. Menurut Wiradyatmika (2013) mengungkapkan bahwa jumlah penduduk dalam pembangunan ekonomi suatu daerah merupakan permasalahan mendasar. Hal tersebut dikerenakan pertumbuhan penduduk yang tidak terkendali dapat mengakibatkan tidak tercapainya tujuan pembangunan ekonomi yaitu kesejahteraan rakyat serta menekan angka kemiskinan.

Seain itu, menurut teori Malthus populasi penduduk cenderung bertambah menurut deret ukur (secara geometris), sedangkan produksi makanan (sumber daya alam) cenderung bertambah menurut deret hitung (secara aritmatika). Akibatnya ketidak seimbangan antara sumberdaya bumi yang tidak mampu memenuhi kebutuhan penduduk yang terus bertambah. Dengan kata lain jika perkembangan sumber daya tidak dapat mendukung perkembangan penduduk maka akan menyebabkan kemiskinan. Menurut Coale-Hoover (dalam Mulyadi, 2008) bahwa pertumbuhan penduduk sebagai pengganggu pembangunan. Hasil ini diperkuat oleh penelitian Wiradyatmika (2013) dan Hakeem et al, (2016) yang menunjukan bahwa jumlah penduduk tidak berpengaruh signifikan. Artinya bertambahnya jumlah penduduk tidak berpengaruh terhadap tingkat kemiskinan. Namun demikian hasil penelitian ini bertentangan dengan Subramanian (2013) yang menemukan jumlah penduduk berpengaruh signifikan terhadap kemiskinan di India. Apabila jumlah penduduk di dominasi oleh usia-usia produktif maka kesempatan kerja dan kesejahteraan hidup semakin tinggi dan kemiskinan berkurang. Variabel pendidikan memiliki koefisien regresi sebesar $-0,7555$ dan memiliki koefisien regresi 0,0308. Hal tersebut menunjukkan bahwa pendidikan berpengaruh negatif dan signifikan terhadap tingkat kemiskinan Kabupaten Wonosobo pada level signifikansi 5 persen. Artinya semakin tinggi tingkat pendidikan penduduk maka tingkat kemiskinan di Kabupaten Wonosobo berkurang. Hasil penelitian ini sesuai dengan penelitian Awan et al., (2011) semakin tinggi pendidikan maka kualitas sumber daya manusia semakin meningkat hal ini akan membuat kesempatan kerja menjadi lebih tinggi, pendapatan masyarakat meningkat dan tingkat kemiskinan akan berkurang.

Hasil penelitian ini sesuai dengan teori human capital invesment. Pendidikan adalah investasi dalam modal manusia setidaknya sama pentingnya dengan investasi dalam modal fisik untuk mencapai kesuksesan ekonomi jangka panjang suatu negara. Investasi dalam modal manusia, sama seperti investasi yang dapat menunjang kesuksesan ekonomi pada suatu wilayah. Semakin tinggi pendidikan maka akan menunjang tingkat kemakmuran masyarakat (Edokpolor dan Ekpenyong, 2016). Selain itu, menurut Todaro (2006) pendidikan di banyak negara merupakan cara untuk menyelamatkan diri dari kemiskinan. Dimana digambarkan dengan seorang miskin yang mengharapkan pekerjaaan baik serta penghasilan yang tinggi maka harus mempunyai tingkat pendidikan yang tinggi. Penduduk miskin tidak mempunyai cukup uang untuk membiayai pendidikan hingga ke tingkat yang lebih tinggi seperti sekolah 
lanjutan dan universitas, sehingga tingkat pendidikan sangat berpengaruh dalam mengatasi masalah kemiskinan. Upah minimum kabupaten memiliki koefisien $-0,0001$ dan nilai probabilitas sebesar 0,0183. Hal tersebut menunjukkan bahwa upah minimum berpengaruh negatif dan signifikan terhadap tingkat kemiskinan Kabupaten Wonosobo pada level signifikansi 1 persen. Hasil penelitian ini sesuai dengan penelitian Akpansung (2014) semakin tinggi tingkat upah minimum maka daya beli masyarakat akan meningkat dan mampu memenuhi kebutuhan hidupnya dan tingkat kemiskinan semakin menurun. Tujuan utama ditetapkan upah minimum adalah memenuhi standar hidup minimum seperti untuk kesehatan, efisiensi, dan kesejahteraan pekerja. Upah minimum adalah usaha untuk mengangkat derajat penduduk berpendapatan rendah, terutama pekerja miskin. Semakin meningkat tingkat upah minimum akan meningkatkan pendapatan masyarakat sehingga kesejahteraan juga meningkat sehingga terbebas dari kemiskinan. Selain itu, penelitian ini sejalan dengan teori David Richardo yang mengatakan bahwa faktor pertumbuhan penduduk yang semakin besar sampai menjadi dua kali lipat pada suatu saat akan menyebabkan jumlah tenaga kerja melimpah. Kelebihan tenaga kerja akan mengakibatkan upah menjadi turun. Upah tersebut hanya dapat digunakan untuk membiayai taraf hidup minimum, sehingga perekonomian akan mengalami keterhambatan (statonary state), sehingga akan berdampak juga pada penurunan tingkat kesejehteraan (Kuncoro, 2009).

Variabel inflasi memiliki koefisien regresi $-0,0639$ dan nilai probabilitas sebesar 0,6342 . Hal tersebut menunjukkan bahwa varaibel inflasi berpengaruh negatif dan tidak signifikan terhadap tingkat kemiskinan Kabupaten Wonosobo. Adanya hubungan yang negatif antara inflasi terhadap kemiskinan, karena adanya kondisi dan situasi di mana daya beli masyarakat dalam suatu daerah bersifat heterogen atau tidak sama, sehingga selanjutnya akan terjadi realokasi barang-barang yang tersedia dari golongan masyarakat yang memilik daya beli yang relatif rendah kepada golongan masyarakat yang memiliki daya beli yang lebih besar. Kejadian ini akan terus terjadi di masyarakat, sehingga laju inflasi akan berhenti hanya apabila salah satu golongan masyarakat tidak bisa lagi memperoleh dana (tidak lagi memiliki daya beli) untuk membiayai pembelian barang pada tingkat harga yang berlaku, sehingga permintaan efektif masyarakat secara keseluruhan tidak lagi melebihi supply barang (inflationary gap menghilang). Hasil ini diperkuat oleh penelitian Imelia (2012) yang menunjukan bahwa inflasi tidak berpengaruh signifikan. Artinya inflasi tidak berpengaruh terhadap tingkat kemiskinan di Kabupaten Wonosobo. Hasil ini bertentangan dengan penelitian Chani et al (2011) yang menunjukan inflasi berpengaruh signifikan terhadap kemiskinan di negara Pakistan. Inflasi akan meningkatkan biaya produksi yang menimbulkan kenaikan harga barang dan jasa, daya beli masyarakat menjadi rendah. Hal ini menyebabkan masyarakat tidak mampu memenuhi kebutuhan hidupnya.

Variabel PDRB memiliki koefisien regresi -5,2086 dan nilai probabilitas sebesar 0,0330. Hal tersebut menunjukkan bahwa varaibel inflasi berpengaruh negatif dan signifikan terhadap tingkat kemiskinan Kabupaten Wonosobo pada level signifikansi 5 persen. Artinya semakin tinggi PDRB maka tingkat kemiskinan Kabupaten Wonosobo akan menurun. Hasil penelitian ini sesuai dengan penelitian Mustika (2011), Puspita (2015) dan Akhtar et al, (2017) jika PDRB tinggi maka pendapatan masyarakat ikut meningkat, kesejahteraan masyarakat akan ikut meningkat dan tingkat kemiskinan menurun. Menurut Siregar \& Wahyuniarti, (2008) menyatakan bahwa pertumbuhan ekonomi merupakan syarat keharusan bagi pengurangan kemiskinan. Adapun syarat kecukupannya ialah bahwa pertumbuhan ekonomi tersebut efekif dalam mengurangi kemiskinan. Artinya pertumbuhan ekonomi tersebut hendaklah menebar di setiap golongan pendapatan, termasuk golongan penduduk miskin (growth with equity). Secara langsung hal ini berarti pertumbuhan ekonomi perlu dipastikan terjadi di sekor-sektor di mana penduduk miskin bekerja (pertanian atau sektor padat karya lainnya). Adapun secara tidak langsung hal itu berarti diperlukan kebijaksanaan pemerintah yang cukup efekif dalam mendistribusi manfaat pertumbuhan yang berasal dari sektor modern seperti sektor jasa, sektor industri, sektor keuangan dan manufakur atau sektor ekonomi yang padat modal. Semakin tinggi PDRB per kapita suatu daerah, maka semakin besar pula potensi sumber penerimaan daerah tersebut dikarenakan semakin besar pendapatan masyarakat daerah tersebut (Kuswantoro dan Dewi, 2016). Hal ini berarti juga semakin tinggi PDRB per kapita semakin sejahtera penduduk suatu wilayah yang dapat ditunjukkan dengan tingginya tingkat konsumsi yang diukur dengan pengeluaran per kapita. Dengan kata lain jumlah penduduk miskin akan berkurang.

\section{Uji Trend Tingkat Kemiskinan Kabupaten Wonosobo}

Untuk mengetahui trend tingkat kemiskinan Kabupaten Wonosobo dalam lima tahun mendatang digunakan data tingkat kemiskinan Data tersebut dikeluarkan oleh Badan Pusat Statistik Jawa Tengah. Dari hasil perhitungan diperoleh persamaan trend tingkat kemiskinan di Kabupaten Wonosobo. Trend tingkat kemiskinan di Kabupaten Wonosobo negative atau menurun dengan $\mathrm{R}^{2}$ 0,875. Untuk lebih jelasnya trend tingkat kemiskinan di Kabupaten Wonosobo lima tahun mendatang dapat dilihat pada Tabel 6. 
Tabel 6.

Hasil Uji trend tingkat kemiskinan Kabupaten Wonosobo tahun 2018-2022.

\begin{tabular}{ll}
\hline Tahun & Tingkat Kemiskinan (Estimasi) \\
\hline 2018 & 20,30 \\
2019 & 19,75 \\
2020 & 18,45 \\
2021 & 17,12 \\
2022 & 15,38 \\
\hline
\end{tabular}

Sumber: Data olahan

Berdasarkan Tabel 6 dapat dilihat bahwa tingkat kemiskinan di Kabupaten Wonosobo pada masa yang akan datang setiap tahunnya akan mengalami penurunan. Pada tahun 2013 tingkat kemiskinan Kabupaten Wonosobo sebesar 20,84 persen dan terus menurun sampai dengan tahun 2017 sebesar 19,12 persen. Penurunan tingkat kemiskinan tersebut akan berpotensi pada penurunan trend tingkat kemiskinan lima tahun yang akan datang. Penurunan tingkat kemiskinan untuk lebih jelasnya dapat dilihat dalam bentuk grafik yaitu tahun 2018 sampai 2022.

Gambar 1.

Trend tingkat kemiskinan Kabupaten Wonosobo tahun 2002-2022

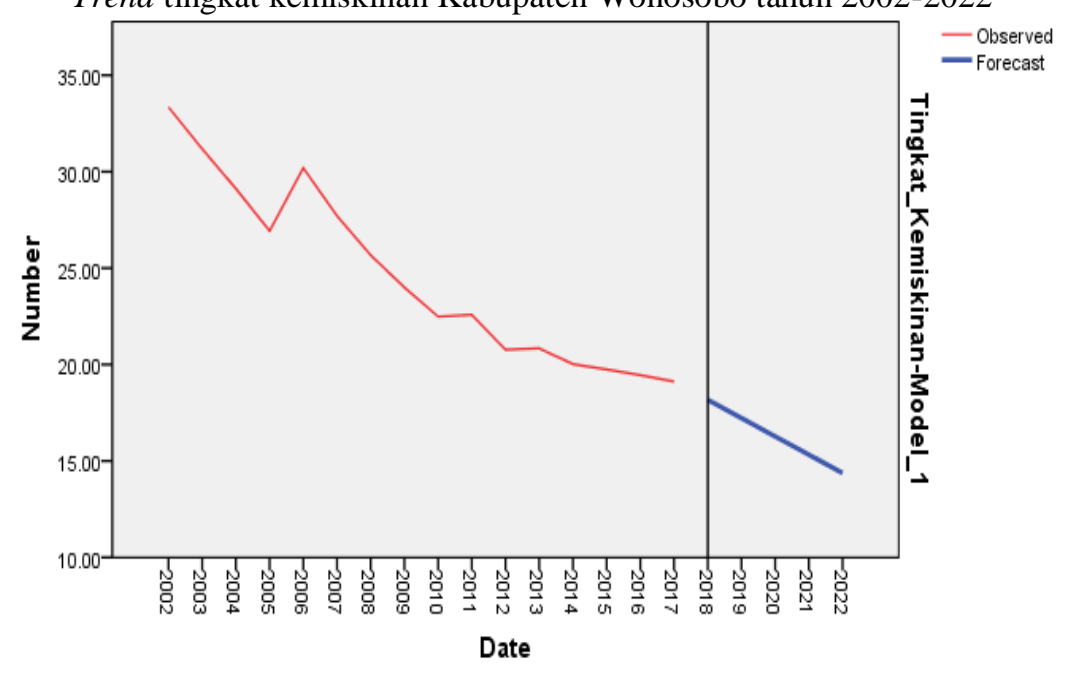

Sumber: data olahan

Trend tingkat kemiskinan Kabupaten Wonosobo dimasa yang akan datang adalah negatif. Artinya tingkat kemiskinan Kabupaten Wonosobo dimasa yang akan datang menurun. Hasil penelitian ini sesuai dengan penelitian Rusdarti \& Sebayang, (2013) yang menunjukan bahwa trend tingkat kemiskinan di Provinsi Jawa Tengah dimasa yang akan datang adalah negatif. Dengan kebijakan yang pro terhadap penduduk miskin dan dukungn stakeholder terkait bukan yang yang mustahil untuk dapat mengurangi jumlah penduduk miskin. Namun demikan, perlu adanya kerjasama yang baik antara pemerintah pusat maupun daerah dalam merumuskan kebijakan dan strategi pengimplementasiannya. Selain itu, pemangku kebijakan harus mengerti kondisi lapangan. Dalam hal ini kondisi kemiskinan disetiap daerah memiliki karateristik yang berbeda, oleh karena itu perumusan dan pengimplementasian kebijakanpun juga harus sesuai dengan kondisi penduduk miskin.

\section{SIMPULAN}

Secara simultan variabel jumlah penduduk, pendidikan, upah minimum, inflasi, dan Produk Domestik Regional Bruto (PDBR) berpengaruh terhadap tingkat kemiskinan di Kabupaten Wonosobo. Secara parsial, variabel jumlah penduduk berpengaruh positif dan tidak signifikan terhadap tingkat kemiskinan di Kabupaten Wonosobo. Variabel pendidikan, upah minimum kabupaten, dan PDRB berpengaruh negatif dan signifikan terhadap tingkat kemiskinan di Kabupaten Wonosobo. Inflasi berpengaruh negatif dan tidak signifikan terhadap tingkat kemiskinan di Kabupaten Wonosobo. Trend tingkat kemiskinan di Kabupaten Wonosobo dimasa yang akan datang adalah negatif.

Memperbaiki sistem pendidikan di Kabupaten Wonosobo, dengan cara memberikan beasiswa pendidikan yang dianggarkan dari Anggarapan pendapatan dan Belanja Daerah (APBD). Pendidikan yang lebih baik diharapkan mampu menghasilkan sumber daya manusia berkualitas dan meningkatkan produktivitas masyarakat. Dengan produktivitas yang tinggi akan meningkatkan masyarakat Kabupaten Wonosobo untuk mendapatkan pekerjaan yang layak, sehingga pendapatan akan bertambah dan kesejahteraan akan dan mampu mengurangi jumlah penduduk miskin di Kabupaten Wonosobo. Selain itu, melakukan upaya peningkatan pertumbuhan Produk Domestik Regional Bruto (PDRB) di setiap sektor lapangan usaha dengan menggunakan potensi-potensi yang dimiliki. Melaksanakan 
pembangunan yang berorientasi pada pemerataan. Mayoritas penduduk Kabupaten Wonosobo berkerja di sektor pertanian dan sektor peternakan sebagai sumber mata pencarian utama. Sektor ini menyumbang lebih dari separuh terhadap pembentukan PDRB Kabupaten Wonosobo. Untuk itu perlu peran aktif pemerintah bersama penduduknya dalam upaya mengembangkan sektor pertanian dan sektor perternakan. Kedua sektor ini merupakan lapangan usaha yang paling banyak ditekuni oleh masyarakat miskin di Kabupaten Wonosobo. Analisis trend menujukkan bahwa di Kabupaten Wonosobo mengalami penurunan sampai dengan tahun 2022. Analisis tersebut dapat sebagai acuhan pemerintah dalam menggukur jumlah kemiskinan di Kabupaten Wonosobo. Namun supaya angka dari analisis trend tersebut dapat terealisasi dengan baik, maka pemerintah harus melakukan kebijakan yang pro poor, seperti memperbaiki sistem pendidikan, menciptakan lapangan pekerjaan, memberikan bantuan, pemberian modal untuk masyarakat miskian dan lainnya. Dengan hal tersebut maka angka kemiskinan akan semakin menurun dan kesejahteraan masyarakat akan meningkat.

\section{DAFTAR PUSTAKA}

Akhtar, R., Liu, H., and Ali, A. (2017). Influencing Factors of Poverty in Pakistan: Time Series Analysis. International Journal of Economic and Financial Issues, 7(2): 215-222.

Akpansung, A. O. (2014). An Empirical Assessment of the Effects of Minimum Wage Increases On Poverty During Democratic Governance in Nigeria. International Journal of Humanities and Social Science. 4(13): 87-98.

Arsyad, L. (2010). Dasar-Dasar Ekonomika Pembangunan. UPP STIM YKPN. Yogyakarta.

Awan, M. S., Malik, N., Sarwar, H., and Waqas, M. (2011). Impact of Education on Poverty Reduction. International Journal of Academic Research, 3(1): 659-664.

Badan Pusat Statistik (Bps). Berita Resmi Statistik. Indikator Penduduk Miskin di Jawa Tengah Tahun 2002-2017.

Badan Pusat Statistik. Berita Resmi Statistik. Jumlah Penduduk Kabupaten Wonosobo Kecamatan Tahun 2000-2015.

Badan Pusat Statistik. Publikasi. Kabupaten Wonosobo Dalam Angka 2017. Kabupaten Wonosobo.

Badan Pusat Statistik. Survei Sosial Ekonomi Nasional (Susenas) Tahun 2018. Angka Partisipasi Murni.

World Bank. (2000). Indonesia: Poverty Assessment And Strategy Report. Report. No. 8034-Ind. Country Department Iii East Asia And Pacific Region. Washington.

Bappenas. (2004). Rencana Pembangunan Jangka Menengah Nasional. Bappenas. Jakarta.

Chani, M. I., Pervaiz, Z., Jan, S. A., Ali, A., Chaudhary, A. R. (2011). Poverty, Inflation And Economic Growth: Emperical Evidence From Pakistan. World Applied Sciences Journal 14(7): 1058-1063.

Departemen Komunikasi dan Informatika Republik Indonesia. (2008). Menuju Pendidikan di Bidang Informasi dan Elektronik. Kominfo. Jakarta.

Dinas Perindustrian dan Tenaga Kerja Kabupaten Wonosobo. (2018). Tingkat Upah Minum Kabupaten. Wonosobo.

Edokpolor, J. E. dan Ekpenyong, E. L. (2016). Winning the War Against Unemployment and Poverty in Nigeria : is there A Role for TVET-Private Sector Partnership. Journal of Nigerian Vocational Education, 1 (2): 125-132.

Endrayani, N, dan Dewi, M. (2016). Analisis Faktor-Faktor yang Mempengaruhi Tingkat Kemiskinan di Kabupaten/Kota di Provinsi Bali. E-Jurnal Ekonomi Dan Bisnis. 7(6): 50-62.

Gujarati, D. (2012). Basic Econometric. Erlangga. Jakarta.

Hakeem, A. O, Emecheta, C \& Ngwudiobu I. M. (2016). Population and Economic Growth in Nigeria: is there an Empirical Evidence of Casuality?. International Journal Advances in Social Science and Humanities, 4(2): 5966.

Hassan, O. M. (2015). The Impact of The Growth Rate of The Gross Domestic Product (GDP) on Poverty Reduction In Nigeria. International Journal of Business Administration, 6(5): 90-100.

Imelia I. (2012). Pengaruh Inflasi Terhadap Kemiskinan di Provinsi Jambi. Jurnal Paradigma Ekonomika. 1(5): 4248.

Kaufman, B. (2000). The Economics Of Labor Markets. Fifth Edition. The Dryden Press. New York.

Keputusan Direktorat Jendral Pemberdayaan Sosial dan Penanggulangan Kemiskinan. (2015). Pedoman Teknis Penggalian dan Pengembangan Potensi Komunitas Adat Terpencil. Kementrian Sosial Ri. Jakarta.

Kuncoro, M. (2009). Ekonomi Pembangunan: Teori, Masalah dan Kebijakan. UPP STIM YKPN. Yogyakarta.

Kuswantoro, K dan Dewi, I. G. P. (2016). Analisis Tingkat Pendidikan, PDRB dan Upah Minimum Regional terhadap Kemiskinan Di Provinsi Banten, Jurnal Ekonomi-Qu, 6(1): 18-34.

Mankiw, N. (2012). Teori Makro Ekonomi. Penerbit Erlangga. Jakarta.

Mulyadi, M. (2008). Ekonomi Sumber Daya manusia Dalam Perspektif Pembangunan. Jakarta : Rajawali Pers.

Candra Mustika. 2011. Pengaruh PDB Dan Jumlah Penduduk Terhadap Kemiskinan di Indonesia Periode 1990 2008. Jurnal Paradigma Ekonomika, 1 (4), hal. 12 - 23.

Peraturan Menteri Tenaga Kerja dan Transmigrasi Nomor 7 tahun 2013 Tentang Upah Minimum.

Puspita, D. W. (2015). Analisis Determinan Kemiskinan Di Provinsi Jawa Tengah. Journal of Economics and Policy, 8(1) 100-107. 
Putri, R. F. (2015). Analisis Pengaruh Inflasi, Pertumbuhan Ekonomi dan Upah Terhadap Pengangguran Terdidik. Economics Development Analysis Journal, 4(2): 175-181.

Rusdarti, dan Sebayang, L. K. (2013). Faktor-Faktor yang Mempengaruhi Tingkat Kemiskinan di Provinsi Jawa Tengah. Jurnal Ekonomia. 9(1): 1-9.

Sekhampu, T. J. (2013). Determinants of Poverty in a South African Township. J Soc Sci, 34(2) 145-153.

Siregar, H dan Wahyuniarti. D. (2008). Dampak Pertumbuhan Ekonomi Terhadap Penurunan Jumlah Penduduk Miskin. Proses Pemerataan dan Kemiskinan. Direktur Kajian Ekonomi. Institusi Pertanian Bogor. Bogor.

Sitepu, R. K, dan Sinaga, B. M. (2007). The Impact Of Human Capital Investment On Economic Growth And Poverty In Indonesia: Computable General Equlibriu, SOCA: Jurnal Sosial Ekonomi Pertanian, 7(2):1-16.

Subramanian, S. (2013). Variable Population and The Measurement Of Poverty and Inequality: A Selective Overview. Indian Economic Review. 48(1): 59-82.

Sukirno, S. (2012). Mikro Ekonomi Teori Pengantar. Edisi Ketiga. Rajagrafindo Persada. Jakarta.

Suryahadi A. dan Sumarto, S. (2001). The Cronich Poor. The Transient Poor, and the Vulerability in Indonesia Before and After Crisis. Semeru Working Paper. Jakarta.

Suryawati, C. (2005). Understanding Multidimension of Poverty. Jurnal Manajemen Pembangunan dan Kebijakan. 8(3): 121-129.

Tambunan, T. (2001). Perekonomian Indonesia, Penerbit Ghalia Indonesia, Jakarta.

Todaro, Michael. Smith, Stephen C. (2006). Economic Developmen. Eight Edition. Terjemahan: Haris Munandar. Erlangga. Jakarta.

UNDP Indonesia, Indonesia Human Development Report. (2004). The Economics Democracy: Financing Human Development in Indonesia. Published Jointly By Bps- Statistic Indonesia.

Widodo, Tri. (2006). Perencanaan Pembangunan (Era Otonomi Daerah). UPP STIM YKPN. Yogyakarta.

Wiradyatmika, A. A. G A dan Sudiana, I. K. (2013). Pengaruh Jumlah Penduduk, Jumlah Penyerapan Tenaga Kerja dan Pengangguran Terhadap Jumlah Penduduk Miskin di Kabupaten Buleleng. E-Jurnal Ekonomi Pembangunan. 2(7): 314-349.

Wirartha, I. M. (2006). Metodologi Penelitian Sosial Ekonomi. C.V Andi Offset. Yogyakarta. 